\title{
LA ANTROPOLOGÍA DE LA RELIGIÓN: UNA CIENCIA INFIEL
}

Nicolás Viotti ${ }^{1}$

La lectura de los trabajos de Bruno Latour que han tocado el tema de la religión presentan una serie de desafíos a los modos en que se han consolidado los estudios sobre el fenómeno religioso en América Latina. Temas caros a esa reflexión son el estatuto de las imágenes, la relación entre "fetiches" y "hechos", la iconofilia y la iconoclastía, los lenguajes religiosos y los lenguajes científicos, la religión como un modo de predicación, un modo de conocimiento, un modo de comunicación y un singular modo de traducción.

Os anjos não produzem bons instrumentos científicos (Latour, 2016) describe dos particulares regímenes de traducción y por lo tanto de verdad. Uno es el que podríamos identificar con el lenguaje religioso de la revelación y la procesión: un modo de traducción que requiere la invención constante para ser una traducción fiel. El segundo es el del descubrimiento, identificado con el saber científico: regulado por la lógica de la referencia y la necesidad de un alineamiento que garantice la estabilidad del mensaje por medio de instrumentos objetivos.

Una serie de cuadros pintados por artistas europeos entre el Siglo XV y el Siglo XVI le permiten a Latour mostrar ese desplazamiento. "Los embajadores" de Hans Holbein encarna la tensión de ambos regímenes, la tensión trágica entre el nuevo mundo geográficamente delineado y el mundo divinizado. "San Jerónimo en su gabinete", de Antonello de Messina, en cambio recrea el orden divino en el horizonte geométrico de la perspectiva. La tensión trágica entre ambos ordenes se disipa en esta obra, la revelación como modo de conocimiento desaparece en el régimen del descubrimiento.

1 Consejo Nacional de Investigaciones Científicas y Técnicas (CONICET). Contacto: nicolas.viotti@gmail.com

Debates do NER, Porto Alegre, ano i7, N. 30, P. 89-94, JUl./Dez. 20 i 6 
La reivindicación de los mediadores en el análisis de la religión desde las ciencias sociales posee el gran mérito de desarmar la "caja negra" de la acción religiosa. Aunque muchos hayan querido ver allí un proceso de igualación que borra las diferencias entre los diferentes regímenes históricamente localizados (¿nunca hemos sido modernos?), este texto de Latour muestra como el ejercicio de simetría está lejos de una lectura homogénea. En realidad, proporciona herramientas que ayudan a entender mejor las diferencias especificas entre regímenes de conocimiento, ya sean religiosos o seculares, y a sofisticar el análisis histórico de las relaciones entre lenguajes religiosos y lenguajes no religiosos desconfiando de la metafísica historicista de la secularización y la modernización.

Pero esa centralidad en el análisis de los mediadores que los lenguajes religiosos movilizan subraya un aspecto que me parece central: una teoría de la traición. Encuentro el foco más sustantivo de su argumento en la descripción de la "polémica sobre los ritos", donde se ponen en juego dos teorías de la comunicación del mensaje religioso. Latour se remite a una controversia sobre la evangelización de Asia que pone en tensión dos ideas distintas de la fidelidad al mensaje religioso romano. Por una parte, la de los dominicos, que se quiere unilateralmente fiel al mensaje romano $y$, por otra parte, la de una "fidelidad transformadora" que requiere de la mutación constante de ese mensaje y, por ende, el peligro de herejía que plantearon los jesuitas. El problema gira en torno a ser fiel al evangelio manteniendo indemne el latín en los ritos católicos, dejando el sentido librado a un juego de interpretaciones basadas sobre todo en juegos fonéticos que se alejan de cualquier sentido original o la traducción del latín a las lenguas nativas y la transformación del evangelio a un horizonte cultural en principio ajeno. Latour nos recuerda que el modelo dominico triunfó, que los jesuitas fueron expulsados de Asia y que el cristianismo perdió la mitad del planeta. Pero nos recuerda también que si el mensaje cristiano no se hubiese "traicionado a sí mismo", es decir que si Jesús, San Pablo, los Padres de la Iglesia y los aislados obispos perdidos entre los visigodos no

Debates do NER, Porto Alegre, Ano I7, N. 30, P. 89-94, JUl./Dez. 20 i 6 
hubiesen transformado y adaptado el mensaje de salvación, nunca hubiésemos escuchado hablar del cristianismo.

Esa descripción no es solo un dato histórico o un análisis de regímenes católicos diferenciados, encierra también una teoría sobre la eficacia del lenguaje religioso. Los términos traducción, transformación y preservación son caros al argumento de Latour en la medida en que ninguno es exclusivo de un régimen específico, sino tres rasgos presentes en ambos, pero con valores diferentes. Esos regímenes corresponden a dos configuraciones lógicas muy concretas y están encarnados idealmente en situaciones históricas también muy concretas. El principio jesuita de "decir de otro modo para poder decir la misma cosa" es una concepción de la circulación transformadora del mensaje religioso que se opone la repetición de lo mismo sin deformación, sostenida por los dominicos.

En cierto modo se describe la posibilidad múltiple del lenguaje religioso como opuesto, pero también simultáneo, a la posibilidad única. Ambas, de modo paradojal, responden a una tensión de la propia cosmología cristiana. Sin embargo, Latour muestra intensidades diferentes, momentos en donde una prima sobre la otra. Por ejemplo, señala la centralidad de una lógica de la mismidad en la reforma protestante y, luego, en la contrarreforma católica que abandona parcialmente su componente revelado y se acerca más al descubrimiento de un mundo "objetivo". El cristianismo, de ese modo, aceptó ser solo una "creencia" y hablar de un "referente", incorporando cada vez más el polo unitario y retrayendo su polo múltiple. La religión se hacía menos barroca y más romana. Pero como señalábamos antes, la posibilidad de la "traición fiel" no es solo una lógica cada vez más minoritaria en el contexto de la contrarreforma, es condición de la eficacia y del éxito del mensaje evangélico. Sin ella, nos recuerda, el cristianismo no hubiese pasado de una ignota secta del Asia Menor.

Este aspecto tiene consecuencias políticas muy importantes que habría que discutir en otro ámbito. Una teoría de la transformación del mensaje excede lo meramente religioso y es una teoría de la cultura que se concentra

Debates do NER, Porto Alegre, ano I7, N. 30, P. 89-94, JUl./Dez. 20 i 6 
en los modos de "publicitación" caros a las redefiniciones contemporáneas entre análisis socio-antropológico e intervención pública. No es necesario ir muy lejos, ni a sociedades "exóticas", para detectar ese proceso de "deformación creativa" de cualquier mensaje y tampoco para convertirlo en principio analítico. Si bien ese es un aspecto sustantivo, por el momento me gustaría decir sólo algo sobre sus posibles consecuencias epistemológicas para las ciencias sociales de la religión en nuestra región.

Os anjos náo produzem bons instrumentos científicos no es solamente una descripción de la transformación de los regímenes de comunicación en la larga duración de la cultura europea posterior a la contrarreforma. Es también una reflexión epistemológica sobre las posibilidades de pensar y analizar a la religión en las ciencias sociales como un régimen de relaciones específico. Este recorrido lleva también a una forma específica de intervenir sobre las discusiones contemporáneas en torno al concepto de "religión" que utilizamos en las ciencias sociales. Forma específica que disputa, por un lado, la imagen de la religión como una metafísica social con una función dadora de "cohesión social" y, por el otro, una metafísica de la experiencia dadora de "sentido". En ese sentido la propuesta de Latour es una propuesta relacional que, sin ser exclusiva ni pionera, presenta un programa sistemático que extiende el modelo de la antropología y la sociología de los modos de vínculo sociales (parentesco o sociabilidad) al análisis de los vínculos con lo sagrado. Esos modos de vínculo, en principio, no son contradictorios con un nivel de abstracción mayor al de su acción práctica. Esa "totalidad", en todo caso, es el efecto de una trama de relaciones y no al revés. Al mismo tiempo, el enfoque desde los modos de vínculo se distancia también de las metafísicas de la experiencia como locus fenoménico de lo religioso, en la medida en que el sentido no es algo "oculto" atrás de un self más o menos universal sino el resultado de una trama de relaciones que incluso permiten descomponer esa unidad mínima de lo humano.

Hay un dialogismo implícito en la propuesta de Latour, en la medida en que, si los lenguajes y las prácticas religiosas que nos toca analizar son algo

Debates do NER, Porto Alegre, Ano I7, N. 30, P. 89-94, JUl./Dez. 20 i 6 
más que un cúmulo de contenidos a descifrar y, por ende, son artefactos transformadores del mundo, también son transformadores del espacio personal y colectivo desde donde los pensamos. Creemos que las consecuencias no pueden olvidar el lugar que los lenguajes religiosos poseen en diferentes espacios nacionales y los modos en que el espacio académico incorpora esa experiencia. Quiero retomar esta impresión del ensayo para plantear una inquietud que hace a la propia circulación de esas ideas en los debates actuales de las ciencias sociales de la religión en la región. Ello nos lleva a dos preguntas: ¿Qué podemos aprender de Os anjos nao produzem bons instrumentos científicos para pensar en problemas de investigación sobre el fenómeno religioso en Argentina y Brasil? ¿En qué medida una definición comunicacional y pragmática del lenguaje religioso impacta diferencialmente en diferentes ámbitos académicos nacionales?

Percibo que la posibilidad de incorporar una definición relacional del lenguaje religioso posee en Brasil una capacidad de asimilación que en Argentina resulta mucho más difícil. La tradición de estudios en donde los procesos de resemantización, sincretismo y "fidelidad transformadora" ha sido utilizada para pensar los lenguajes religiosos tiene en Brasil un largo linaje. Resulta allí tan importante la "creatividad religiosa" de los fieles, como rasgo general de la llamada "cultura nacional", como una serie de análisis que priorizaron "enfoques epistemológicos abiertos", presentes en muchos cientistas sociales que han hecho de una característica empírica de algunas zonas de la sociedad brasilera una propuesta teórica. En Argentina, como ya ha sido señalado algunas veces, la posibilidad de encontrar esos procesos a nivel empírico no siempre fue acompañada de sociólogos y antropólogos que la reivindiquen analíticamente. Por el contrario, salvo excepciones, ha primado una tradición del análisis de lo religioso que prioriza la lógica de la mismidad y la "referencia". Las razones de esa diferencia, que sin duda está en un proceso de fuerte cuestionamiento, posiblemente tienen que ver con imágenes y autoimágenes solidificadas sobre el estatuto "moderno" y por lo tanto "secular" de la sociedad argentina que tamizan a las propias ciencias sociales, sus objetos y sus enfoques privilegiados.

Debates do NER, Porto Alegre, Ano I7, N. 30, P. 89-94, JUl./Dez. 20 i 6 
Eso no quiere decir que los procesos de secularización no hayan sido parcial y diferencialmente eficaces ni que existan recursos analíticos que puedan dar cuanta de esa singularidad, sino que las ciencias sociales sean sensibles y auto-reflexivas con respecto a las narrativas dominantes que invisibilizan la diversidad y las diferencias entre regímenes religiosos.

En una célebre ficción de Jorge Luis Borges, el teólogo Nils Runeberg especula sobre la imagen clásica cristiana de la traición encarnada en Judas. Borges imagina un Runeberg con una singular hipótesis, considerada unánimemente como herética, de que Judas entregó a Jesucristo por razones metafísicas: forzarlo a declarar su divinidad y así encender una vasta rebelión contra el yugo de Roma. La traición de Judas no fue un hecho casual, estaba prefijada y era parte de una economía de la redención en la que Judas fue el mediador, en el sentido sacrificial que nos enseña la antropología, del mensaje de Cristo. En cierto modo Judas Iscariote reflejó, sostiene Borges, a Jesús. La traición es aquí, como en la "fiel-herejía" jesuita, y quizás también en la imagen del ángel caído, la posibilidad de un mensaje religioso que se "haga presente".

Esta imagen de la traición como algo inherente a la eficacia del lenguaje religioso es impensable sin "mediadores" que transporten y transformen el mensaje mismo. Los jesuitas, Judas y el ángel caído hacen a ese particular régimen de verdad y de traducción. Efectivamente, para la obra de Bruno Latour así como para otros linajes europeos, norteamericanos y para tradiciones importantes de las ciencias sociales de la religión latinoamericanas, los ángeles son buenos instrumentos científicos. Reconocer esas tradiciones heterogéneas, ponerlas en relación en un intercambio regional, es un desafío que bien puede potenciar un diálogo necesario. La eficacia social de esa circulación tendrá que ver con cuan fieles y heréticos podamos ser con las viejas y nuevas herramientas para pensar el lenguaje religioso. 